\author{
A.R. Yeshkeyev, G.A. Urken \\ Ye.A.Buketov Karaganda State University, Kazakhstan \\ (E-mail: aibat.kz@gmail.com)
}

\title{
The admissibility and similarity of Jonsson theories
}

\begin{abstract}
This work is related to the concepts of admissibility, interpretability, syntactic similarity and semantic similarity of Jonsson's theories. This new concept generalize the notion of syntactic and semantic similarities for Jonsson theories. In the frame of study of preservation of the definable formulas subsets of Jonsson theory's semantic model regarding to considering morphisms the concepts of admissibility, interpretability, domination and similarity play a very important role. As an example, we consider the theory of Boolean algebras. These concepts are closely related to the concept of admissibility by one theory on the other. The interest of this paper is that the examples examined show the fact that admissibility, interpretability and similarity can be considered on algebras of different signatures.In this work the main definitions of notions and the basic directions of further researches are studied.
\end{abstract}

Keywords: Jonsson theory, semantic model, admissibility, interpretability, domination of Jonsson theories, syntactic and semantic similarity.

One of the classical problems of science is the question of classifying objects of study on some common features. In mathematics, the role of such objects is played sets with given relations. With the help of mathematical logic, these objects were associated with some sets of formulas of the predicate calculus's language. This relation between the syntax and semantics of a fixed language is actually the essence of Model Theory. Therefore, it is clear that finding the syntactic and semantic features of similarity can be useful in classifying objects of Model Theory.

In this paper, we compare the notions of admissibility and similarity for complete and Jonsson theories. At one time Professor T.G. Mustafin [1] in the language of pure pair and semantic triples defined the notion of admissibility, interpretability and syntactic and semantic similarity between two complete theories.In connection with the fact that any complete theory with the help of certain manipulations (enrichment of signature and morlization) can lead to a theory that will be Jonsson theory. In addition, after morlization, the structure and number of models of the newly obtained theory in a certain sense will not differ much from the structure and number of models for the original complete theory.The remark «in a certain sense» can be deciphered in the following way: in connection with the fact that when dealing with Jonsson theories we are dealing with the class of existentially closed models of the considering theory, one can note that morlization with existentially closed models of originally complete theory (if they exist) do not change the structure and the number of these models. The next fact, connected with the existence of existentially closed models of complete theories, forces us to be in the class of complete inductive theories, because it is well that any model of an inductive theory is embedded isomorphically into some existentially closed model of this theory.

T.G. Mustafin in his work [2] defined the exact concept of syntactic [2 (Def. 1)] and semantic similarity [2 (Def. 4)] of complete theories. Moreover, in the language of these definitions and corresponding concepts (eg, the hull of theory [2 (Def. 12)], the semantic property (of theory, model, element) [2 (Def. 8]), he proved that for an arbitrary complete theory there exists syntactically similar to it some theory of polygons [2, Th. 4, Th. 5].

In this paper, we give a material that explains the connection with the various concepts of similarity between Jonsson theories. By means of a generalization of some definitions from [2] and the technique of working with Jonsson theories, it was obtained that in the class of perfect $\exists$-complete Jonsson theories the concepts of the introduced similarities of Jonsson theories coincide with the corresponding concepts in general theorems in the sense of [2]. In the class of Jonsson theories this approach to the classification of the corresponding objects is acceptable, but requires certain changes in the definitions of the corresponding similarities of theories. This is due, first, to the fact that, generally speaking, the Jonsson theories are not complete, and secondly, that in the class of models of Jonsson theory, homogeneous-universal models are, generally speaking, not saturated. Thus, all of the above suggests that the redefinition of the basic attributes of such concepts as permissibility, interpretability and similarity in the class of Jonsson theories is an actual task. On the other hand, the research of Jonsson theories is interesting in and of itself, regardless of the reduction of some complete theory to the Jonsson theory. The 
point is that the class of Jonsson theories of fixed signature is, generally speaking, incomplete, yet inductive and with the amalgam property and the joint embedding property, which are natural for many algebraic problems.

We give the definitions from [1].

Definition 1. If $A$ is non-empty set, $G$ is some group of bijections (permutations) of the set $A$ concerning superposition then the pair $(A, G)$ is called pure pair. If $(B, H)$ and $(A, G)$ are pure pairs, $B \subseteq A$ and $H=\{g \uparrow B ; g \in G\}$ then pure pair $(B, H)$ is called subpair of pure pair $(A, G)$ and we denote $(B, H) \subseteq(A, G)$.

Definition 2. We say that pure pairs $(A, G)$ and $(B, H)$ are isomorphic, if exists such bijection $\psi: A \rightarrow B$ that $H=\left\{\psi g \psi^{-1} ; g \in G\right\}$. In this case we will write $\psi:(A, G) \simeq(B, H)$. If $A=B, H$ is a subgroup of group $G$ then we will use record $(B, H)[=, \leq](A, G)$. If there is such pure pair $(G, F)$ that $(B, H) \simeq(G, F)[=, \leq](A, G)$ we will write $(B, H)[\simeq, \leq](A, G)$.

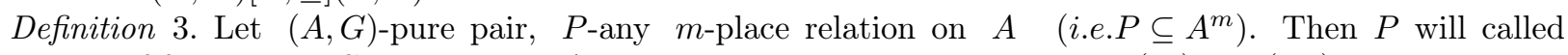
$G$-invariant if for any $g \in G, a_{1} \ldots, a_{m} \in A$ takes place $<a_{1} \ldots, a_{m}>\in P \Rightarrow<g\left(a_{1}\right) \ldots, g\left(a_{m}\right)>\in P$.

Through $G_{m}$ we will denote the set of all such permutations $f$ of set $A^{m}$ or which exist such $g \in G$ that $f\left(<a_{1} \ldots, a_{m}>\right)=<g\left(a_{1}\right), \ldots, g\left(a_{m}\right)>$ for all $a_{1}, \ldots, a_{m} \in A$. It is obvious that the pair $\left(A^{m}, G_{m}\right)$ is pure pair. If $\sim$ is $G$ - the invariant relation of equivalence then $\sim$ induces on $G$ group congruence which also we will denote through $\sim$ as follows:

$$
g_{1} \sim g_{2} \Leftrightarrow g_{1}(a) \sim g_{2}(a) \text { for all } a \in A
$$

Clearly that $(A / \sim, G / \sim)$ will be pure pair if to put $\tilde{g}(\tilde{a})=g(a)$ for all $g \in G, a \in A$ where $\tilde{a}$, $\tilde{g}$ - coset classes on $A$ and $G$ accordingly.

Definition 4. Pair $(B, H)$ is called derivative pure pair from pure pair $(A, G)$ if exists such $n<\omega$ and $G_{n}$ - the invariant relation of equivalence $\sim$ on $A$ that $(B, H) \subseteq\left(A^{n} / \sim, G^{n} / \sim\right)$. We say that pure pair $(A, G)$ dominates over pure pair $(C, F)$ if there is such derivative pure pair $(B, H)$ from $(A, G)$ that $(B, H)[=, \leq](C, F)$.

Family of subsets (relations) $p_{i} \subseteq A^{n_{i}}, i \in I$, we name complete family on pure pair $(A, G)$ if $G$ is group of all automorphisms algebraic system $<A ; P_{i}, i \in I>$ (i.e $\left.G=A u t\left(<A ; P_{i}, i \in I\right\rangle\right)$.

Let $\tau$ - some way allowing for any pure pair $(A, G)$ to allocate some system of $G$ - invariant relations on $A$ (so-called $\tau$-relations). We say that the algebraic system $<C ; R_{i}, i \in I>$ - is interpreted in pure pair $(A, G)$ if exist such $n<\omega, P \subseteq A^{n}$ and surjection $\psi: P \rightarrow C$ that complete prototypes $R_{i} i \in I$, and equality relations are $\tau$-relations on $A$. We say that pure pair $(C, F), \tau$ is interpreted in $(A, G)$ if exist such complete family of relations $R_{i} \subseteq C^{n_{i}}, i \in I$, on $(C, F)$ that $\left\langle C ; R_{i}, i \in I\right\rangle, \tau-$ is interpreted $(A, G)$.

Definition 5. Let, $\mathfrak{A}, \mathfrak{B}$ are arbitrary mathematical structures in the Bourbaki's sense on sets $A, B$ accordingly, $G=\operatorname{Aut}(\mathfrak{A}), G=\operatorname{Aut}(\mathfrak{B})$. We say that:

1) $\mathfrak{A}$ admits $\mathfrak{B}$ (or $\mathfrak{B}$ it is admissible $\mathfrak{A}$ ), if $(A, G)[\simeq, \leq](B, H)$;

2) $\mathfrak{A}$ relatively admits $\mathfrak{B}$, if $(A, G)$ dominates over $(B, H)$.

Remark 1 . If $\mathfrak{A}$ admits $\mathfrak{B}$, then $\mathfrak{A}$ relatively admits $\mathfrak{B}$.

If $K$ is the class of mathematical structures then we say that $\mathfrak{A}$ admits (relatively admits) $K$ if and only if when $\mathfrak{A}$ admits (relatively admits) some structure from $K$. If the class $K$ is defined by system of axioms $\Sigma$ then

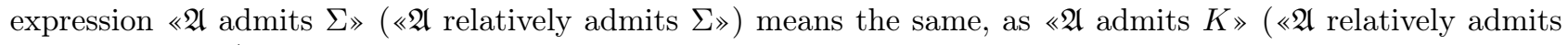
$K$, accordingly»).

If $T$ is the complete theory of algebraic systems of the first order language then we say that $T$ (relatively) admits a class $K$ of mathematical structures (or system of axioms $\Sigma$ ) if the monster-model $\mathfrak{C}$ of theory $T$ (relatively) admits $K$ ( $\Sigma$ accordingly).

One of the important concepts of Model Theory is the concept of definability (interpretability) of one algebraic system in another. It is said that the algebraic system $\mathfrak{B}=<B, R_{i}, i \in I>$ is definable on $\mathfrak{A}=<A, P_{j}, j \in J>$,if exists such formular relations $\Phi_{i} i \in I$ in language $\mathfrak{A}$ that $<A ; \Phi_{i}, i \in I>$ is isomorphic $<B ; R_{i}, i \in I>$. In the course of the development of model theory, this notion was generalized, and the most general (at present) definition can be formulated as follows. If $\mathfrak{A}$ algebraic system $n<\omega B \subseteq A^{n}, \lambda$ is the cardinal then $B$ is called $\tau_{\lambda}$-subset if exists such $n$-type $p\left(x_{1}, \ldots, x_{n}\right)$ over $\emptyset$ of language of system A, such $\left|p\left(x_{1}, \ldots, x_{n}\right)\right|<\lambda$ and $B$ consists of all $n$ of $A^{n}$, realising $p\left(x_{1}, \ldots, x_{n}\right)$ in $\mathfrak{A}$. Obviously, $\tau_{\lambda}$-subsets are invariant relatively automorphisms. Therefore, $\tau_{\lambda}$ it can be considered as a way of isolating a certain class of invariant subsets of algebraic systems. If $\mathfrak{A}, \mathfrak{B}$ - algebraic systems $G=A u t(\mathrm{~A})$, then we say that $\mathfrak{B}$ is $\tau_{\lambda}-$ interpreted in $\mathfrak{A}$, if $\mathfrak{B}$, is $\tau_{\lambda}$ - interpreted in pure pair $(A, G)$. If $\lambda=\omega$ then usually instead of $\tau_{\lambda}$ - interpretability says formally (or elementarily) interpreted (definable).

We redefine the notion of a pure triple in the frame of the study of Jonsson theories. First we recall the original definition of a pure triple from [1]. 
Definition 6. A triple $(A, G, N)$ is called a pure triple, if:

1) $(A, G)$ is pure pair;

2) $N$ - some class of subsets $A$ such that $g(M) \in N$ for all $M \in N g \in G$, where $g(M)=\{g(a): a \in M\}$.

If $(A, G, N),\left(A^{\prime}, G^{\prime}, N^{\prime}\right)$ - pure triples, $\varphi: A \rightarrow A^{\prime}$ bijection then $\varphi$ is called as exact similarity (isomorphism), if:

a) $G^{\prime}=\left\{\varphi g \varphi^{\prime}: g \in G\right\}$

б) $N^{\prime}=\{\varphi(M): M \in N\}$.

If $(A, G, N)$ - a pure triple, $\sim-G$ - the invariant relation of equivalence on $A$ then $\sim$ is called a congruence on $(A, G, N)$, if $\forall a \in A, \forall M \in N(a \in M \Rightarrow \tilde{a} \in M)$.

$\operatorname{If}(A, G, N),\left(A^{\prime}, G^{\prime}, N^{\prime}\right)$ - pure triples, $\varphi: A \rightarrow A^{\prime}$ - surjection then $\varphi$ is called a compression and $\varphi^{-1}$ is inflating, if:

1) The relation $\widetilde{\varphi}$ is congruence, where $a \widetilde{\varphi} b \Longleftrightarrow \varphi(a)=\varphi(b), a, b \in A$;

2) The mapping $\psi: A^{\prime} \rightarrow A / \sim$ is exact similarity, where $\psi\left(a^{\prime}\right)=\left\{a \in A: \varphi(a)=a^{\prime}\right\}, a^{\prime} \in A^{\prime}$.

Let $T$ is a complete theory, $\mathfrak{C}$ is its monster-model, $G=\operatorname{Aut}(\mathfrak{C}), N$ - a class of all elementary submodels $\mathfrak{C}$, smaller it on capacity. Then a pure triple $(\mathfrak{C}, G, N)$ will be called a semantic triple of theory $T$. Complete theories $T_{1}, T_{2}$ will be called semantically exactly similar if their semantic triple are exactly similar.

Remark 2. The notion of exact similarity of theories does not depend on the choice of monster -models and the semantic model.

Definition 7 [2]. Let $T_{1}$ and $T_{2}$ are complete theories. We will speak, as $T_{1}$ and $T_{2}$ are syntactically similar, if $f: F\left(T_{1}\right) \rightarrow F\left(T_{2}\right)$ exists bijection such that

1) restriction $\mathrm{f}$ to $F_{n}\left(T_{1}\right)$ is isomorphism of Boolean algebras $F_{n}\left(T_{1}\right)$ and $F_{n}\left(T_{1}\right), n<\omega$;

2) $f\left(\exists v_{n+1} \varphi\right)=\exists v_{n+1} f(\varphi), \varphi \in F_{n+1}(T), n<\omega$

3) $f\left(v_{1}=v_{2}\right)=\left(v_{1}=v_{2}\right)$.

Let $T$ is an arbitrary Jonsson theory, then $E(T)=\bigcup_{n<\omega} E_{n}(T)$, where $E_{n}(T)$ is a lattice of $\exists$-formulas with $n$ free variables, $T^{*}$ is a center of Jonsson theory $T$, i.e. $T^{*}=T h(C)$, where $C$ is semantic model of Jonsson $T$ theory in the sense of [3].

Definition 8 [4]. Let $T_{1}$ and $T_{2}$ are arbitrary Jonsson theories. We say, that $T_{1}$ and $T_{2}$ are Jonsson's syntactically similar, if exists a bijection $f: E\left(T_{1}\right) \longrightarrow E\left(T_{2}\right)$ such that

1) restriction $f$ to $E_{n}\left(T_{1}\right)$ is isomorphism of lattices $E_{n}\left(T_{1}\right)$ and $E_{n}\left(T_{2}\right), n<\omega$;

2) $f\left(\exists v_{n+1} \varphi\right)=\exists v_{n+1} f(\varphi), \varphi \in E_{n+1}(T), n<\omega$;

3) $f\left(v_{1}=v_{2}\right)=\left(v_{1}=v_{2}\right)$.

Definition 9 [4]. The pure triple $\langle C, A u t C, S u b C\rangle$ is called the Jonsson semantic triple, where $C$ is semantic model of $T, A u t C$ is the automorphism group $C, S u b C$ is a class of all subsets of the carrier $C$, which are carriers of the corresponding is existentially-closed submodels of $C$.

Definition 10 [4]. Two Jonsson theories $T_{1}$ and $T_{2}$ are called Jonsson's semantically similar if their Jonsson semantic triples are isomorphic as pure triples.

The main result of this paper is the following result, related to the above definitions.

Theorem 1. Let $T_{1}$ and $T_{2}$ are $\exists-$ complete perfect Jonsson theories. Then following conditions are equivalent:

1) $T_{1}$ and $T_{2}$ are Jonsson's syntactically similar;

2) $T_{1}^{*}$ and $T_{2}^{*}$ are syntactically similar (in the sense of [2]).

The following two facts are necessary for the proof.

Fact 1. For any Jonsson theory $T$ following conditions are equivalent

1) $T$ is perfect;

2) $T^{*}$ is the model complete.

Proof: follows from the fact that the perfectness of the Jonsson theory $T$ is equivalent to that $T^{*}$ is the model companion of the theory $T$ [5 (the proposition 3.4)], [6].

Fact 2. For any complete for $\exists$ - sentences of Jonsson theory $T$ the following conditions are equivalent:

1) $T^{*}$ is model complete;

2) for each $n<\omega, E_{n}(T)$ is Boolean algebra, where $E_{n}(T)$ is a lattice of $\exists$ - formulas with $n$ free variables.

Proof: 1$) \Rightarrow 2$ ) Let $T^{*}$ is the model complete $\Rightarrow E_{n}\left(T^{*}\right)$ is Boolean algebra, since $T^{*}$ is complete theory (elementary theory of semantic model), but $E_{n}(T) \subseteq E_{n}\left(T^{*}\right)$, since $T \subseteq\left(T^{*}\right)$.

We have 2 cases:

1) $T$ - complete, $T=T^{*}$ then $\Rightarrow T$ is model $\Rightarrow E_{n}(T)$-complete is Boolean algebra;

2) So $T \subset T^{*} \Leftrightarrow T^{*}=T h(C)$ where is $C$ semantic model of $T$, then $\forall \varphi \in T \Rightarrow \varphi \in T^{*}$. 
Since $T$ is complete for $\exists$-sentences, then all the $\exists$-sentences deducing from $T$, belong to $T^{*}$. There are no other $\exists$-sentences in $T^{*}$, since $T$ is complete for $\exists$-sentences $T^{*}$ is a complete theory. Since $E_{n}\left(T^{*}\right)$ is Boolean algebra, then in it there are complements for any $\varphi \exists$-sentense. In general this $\varphi$ will not be $\exists$-sentence, as if $\varphi \in \Sigma$, then $\neg \varphi \in \Pi$ ( $\Sigma$-set of $\exists$-sentences and $\Pi$ is the set of $\forall$-sentences), but $T^{*}$ is modelcomplete $\Leftrightarrow \forall \psi \in T, \exists \theta \in T^{*}: \psi \equiv \theta, \theta \in \Sigma$. But we know, that $\left.\theta \in T^{*} \Leftrightarrow \theta \in T \Rightarrow 1\right) 1,0 \in E_{n}(T)$; 2) $\varphi \in E_{n}(T) \Rightarrow \neg \varphi \in E_{n}(T)$; 3) $\forall \varphi \in E_{n}(T) \neg \neg \varphi=\varphi \Rightarrow E_{n}(T)$ is the Boolean algebra.

$2) \Rightarrow 1) E_{n}(T)$ is the Boolean algebra $\Rightarrow T$ is model complete, but $T \subset T^{*}=T h(C)$. Let $A \in \operatorname{Mod} T \Rightarrow A$ isomorphically embedded in $C$, since $C$ is semantic model. By virtue of that is model complete, $\Rightarrow$ this embedding is elementary.

Let $C$ it not saturated, then $\exists X \subset C,|X|<|C|, \exists p \in S_{1}(X)$ : it is incorrect, that $(C, x)_{x \in X} \mid=p$, but $p \cup T$ - jointly, $p \cup T^{*}$ jointly, therefore $\exists m \notin C: m$ realizes $p$, then, $\exists M \models T^{*}$ that, $m \in M$, is an elementary extension of $C$ of that power $\Rightarrow$ there is a semantic model $C^{\prime}$, which is $|M|^{+}$- saturated and elementary extension of $M$ of power $2^{|M|}$

But any two semantic models are elementarily equivalent to each other, in particular $C \equiv C^{\prime}$. We received contradiction since in $C^{\prime}$ is $p$ realised. Consequently, our assumption, that $C$ is unsaturated, wrong $\Rightarrow T$ is perfect $\Rightarrow T^{*}$ is model complete.

We now proceed directly to the proof of the theorem.

Let's show 1$) \Rightarrow 2)$. We have that for each is $n<\omega, E_{n}\left(T_{1}\right)$ isomorphic to $E_{n}\left(T_{2}\right)$. Let this isomorphism be realized by $f_{1 n}$. By virtue of condition of the theorem and facts 1 and 2 , for each $n<\omega, E_{n}\left(T_{1}\right)$ and $E_{n}\left(T_{2}\right)$ are the Boolean algebras.

But by virtue of perfection $T_{1}$ and $T_{2} \Rightarrow T_{1}^{*}$ and $T_{2}^{*}$ are model-complete by virtue of fact 1 , therefore for each $n<\omega$, for any formula $\varphi(\bar{x})$ from $F_{n}\left(T_{1}^{*}\right)$ there is a formula $\psi(\bar{x})$ from $E_{n}\left(T_{1}^{*}\right)$ such, that $T_{1}^{*}=\varphi \leftrightarrow \psi$. Due to the fact that the theory $T_{1}$ is $\exists-$ complete and $E_{n}\left(T_{1}\right) \subseteq E_{n}\left(T_{1}^{*}\right)$, (since $\left.T_{1} \subseteq T_{1}^{*}\right)$, it follows, that $E_{n}\left(T_{1}\right)=E_{n}\left(T_{1}^{*}\right)$. Due to the fact that the theory $T_{2}$ is $\exists-$ complete and $E_{n}\left(T_{2}\right) \subseteq E_{n}\left(T_{2}^{*}\right),\left(\right.$ since $\left.T_{2} \subseteq T_{2}^{*}\right)$, it follows, that $E_{n}\left(T_{2}\right)=E_{n}\left(T_{2}^{*}\right)$.

For each, $n<\omega$, for each $\varphi_{1}(\bar{x})$, from $F_{n}\left(T_{1}^{*}\right)$ we set the following mapping between $F_{n}\left(T_{1}^{*}\right)$ and $F_{n}\left(T_{2}^{*}\right): f_{2 n}\left(\varphi_{1}(\bar{x})\right)=f_{1 n}\left(\psi_{1}(\bar{x})\right)$, where $T_{1}^{*} \models \psi_{1} \leftrightarrow \varphi_{1}, \psi_{1} \in E_{n}\left(T_{1}\right)$.

It is easy to see that, by virtue of properties $f_{1 n}$ and the above $f_{2 n}$ is a bijection defining an isomorphism between $F_{n}\left(T_{1}^{*}\right)$ and $F_{n}\left(T_{2}^{*}\right)$. Hence $T_{1}^{*}$ and $T_{2}^{*}$ are syntactically similar.

We will show 2$) \Rightarrow 1$ ). It is trivial, as $F_{n}\left(T_{1}^{*}\right)$ is isomorphic $F_{n}\left(T_{2}^{*}\right)$ for each $n<\omega$, and the theorem and facts 1 and 2, this isomorphism extends to all subalgebras..

The following result is known from [2].

Proposition 1 . If the theories $T_{1}$ and $T_{2}$ are syntactically similar, then $T_{1}$ and $T_{2}$ semantically similar, the converse is not true.

In connection with this, we can formulate the following:

Lemma 1. Any two cosemantic Jonsson theories are Jonsson's semantically similar.

The proof follows from the definition.

Lemma 2. If two perfect $\exists$-complete Jonsson theories are Jonsson's syntactically similar, then they are Jonsson's semantically similar.

Proof. Follows from Theorem 1 and Proposition 1.

All the definitions and concepts that are not defined here, connected with the Jonsson theories, can be found in $[4]$.

Returning to the concepts of admissibility, interpretability, and similarity from [1], we recall that theories $T_{1}$ and $T_{2}$ are called $\tau-$ similar if there are satisfying models $M_{1}=T_{1}, M_{2}=T_{2}$, such that $T h\left(M_{1}, m\right)_{m \in M_{1}}$ and $T h\left(M_{2}, m\right)_{m \in M_{2}} \varepsilon$ are similar.

The following result is correct:

Proposition 2 [1]. 1) If $T_{1}$ and $T_{2} \varepsilon$ - similar, $M_{i} \in N_{i}, M_{1} \rightarrow M_{2}$ then $T h\left(M_{1} m\right)_{m \in M_{1}}$ and $T h\left(M_{2}, m\right)_{m \in M_{2}}$, $\varepsilon$ are similar.

The $\ll \tau-$ similarity» relation is an equivalence relation.

It is absolutely analogous, as in the case of complete theories, that all the above concepts can be redefined, namely, admissibility, interpretability, dominance, $\tau$ - similar to the case of Jonsson theories. Further, all results and their corollaries on $\tau$ - similarity in the sense of [1] can be correlated to the study of the syntactic and semantic similarity of Jonsson theories in the above. We note that the syntactic similarity of two Jonsson theories, defined above preserves all types of morphisms proposed for the study of Jonsson theories in the frame 
of the study of Jonsson analog of $\tau$ - similarity for complete theories. In conclusion, we note that this topic also has a promising continuation in the frame of the study of Jonsson sets in the given Jonsson theories [7-9].

We would like to give some examples of syntactic similarity of certain algebraic examples. Fot this, we recall the basic definitions associated with these examples following denotions from B. Poizat [10].

A Boolean ring is an associative ring with identity, in which $x^{2}=x$ for any $x$ is called a Boolean ring; then, we have also $(\mathrm{x}+\mathrm{y})^{2}=x^{2}+x y+y x+y^{2}=x+x y+y x+y$ and besides $(x+y)^{2}=x+y$; therefore $x y+y x=0$ for an arbitrary $x, y ; x^{2}+x^{2}=0$ means $x+x=0$, for any $x$ or $x=-x$; hence the Boolean ring has characteristic 2 and, since $x y=-y x=y x$, it is commutative.

To axiomatize this concept, we introduce a language containing two symbols of constants 0 and 1 , two symbols of binary relations + and .

We write down some universal axioms expressing that $\mathrm{A}$ is the Boolean ring, without forgetting thus $0 \neq 1$. In the Boolean ring we will define two binary operations $\wedge$ and $\vee$, and unary operation $\neg$ as follows: $x \wedge y=x \cdot y$; $x \vee y=x+y+x y ; \neg x=1+x$.

It is easy to verify that the following are true for all $\mathrm{x}, \mathrm{y}$ and $\mathrm{z}$ :

(de Morgan's laws or duality): $\neg(\neg x)=x, \neg(x \wedge y)=\neg x \vee \neg y \neg(x \vee y)=\neg x \wedge \neg y$;

$x \vee x=x \wedge x=x$

(associativity $\wedge):(x \wedge y) \wedge z=x \wedge(y \wedge z)$

(associativity $\vee):(x \vee y) \vee z=x \vee(y \vee z)$;

(distributivity $\wedge$ over $\vee): x \wedge(y \vee z)=(x \wedge y) \vee(x \wedge z)$;

(distributivity $\vee$ over $\wedge): x \vee(y \wedge z)=(x \vee y) \wedge(x \vee z)$;

(commutativity $\wedge$ over $\vee$ ): $x \wedge y=y \wedge x, x \vee y=y \vee x$;

$x \wedge \neg x=0, x \vee \neg x=1$;

$x \wedge 0=0, x \vee 0=\mathrm{x}, x \wedge 1=x, x \vee 1=1$;

$0 \neq 1, \neg 0=1, \neg 1=0$.

A structure in language $>0,1, \neg, \wedge, \vee$ satisfying to these universal axioms is called a Boolean algebra.

Fact 3 [10]. In each Boolean ring one can interpret a certain Boolean algebra.

Proof. With the Boolean ring $A$ we have connected some Boolean algebra $b(A)$; the converse is also true: $x \cdot y=x \wedge y x+y=(x \vee y) \wedge(\neg x \vee \neg y)$ then we receive the Boolean ring $a(B)$; and besides $a(b(A))=A$ $b(a(B))=B$. Thus we see that, up to a language, the Boolean ring and Boolean algebras have the same structures, the Boolean ring canonically is transformed into a Boolean algebra and vice versa, transformations in both directions are carried out using quantifier-free formulas

The following example connects Boolean algebras with abelian groups.

Fact 4 [11]. In each Boolean algebra one can interpret an Abelian group.

Proof. In Boolean algebra $A$ we suppose $a+b=\left(a \wedge b^{\prime}\right) \vee\left(a^{\prime} \wedge b\right)$.

$[A,+]$ is Abelian group and in which each not unit element has an order 2.

The element 0 is group unit in $\mathrm{G}$, and each element $x$ is reciprocal to itself: $x+x=0$ for all $\mathrm{x} \in \mathrm{A}$.

We state the obtained results.

Let's denote through $T_{B A}, T_{B R}, T_{A G}$ accordingly theories in their signatures (they are different) of Boolean algebras, Boolean rings, and Abelian groups.

Lemma 3. $T_{B A}, T_{B R}, T_{A G}$ are examples of Jonsson theories.

Proof. $T_{B A}$ and $T_{B R}$ from [4], $T_{A G}$ from [12].

Theorem 2. Theories $T_{B A}$ and $T_{B R}$ are syntactically similar, and mutually interpreted among themselves, as for complete theories and for Jonsson theories.

Proof. Follows from the fact 3.

Theorem 3. Theory $T_{B A}$ is interpreted in theory $T_{A G}$, as for complete theories and for the Jonsson theories.

Proof. Follows from fact 2 and Theorem 2.

\section{References}

1 Мустафин Т.Г. Введение в прикладную теорию моделей / Т.Г.Мустафин, Т.А.Нурмагамбетов. Караганда: Изд-во КарГУ, 1987. - 94 с.

2 Mustafin T.G. On similarities of complete theories / T.G.Mustafin // Logic Colloquium '90. Proceedings of the Annual European Summer Meeting of the Association for Symbolic Logic. - Helsinki, 1990. P. 259-265. 
3 Mustafin Y. Quelques proprietes des theories de Jonsson / Y.Mustafin // The Journal of Symbolic Logic. - 2002. - Vol. 67. - No. 2. - P. 528-536.

4 Ешкеев А.Р. Йонсоновские теории и их классы моделей: монография / А.Р.Ешкеев, М.Т.Касыметова. - Караганда: Изд-во КарГУ, 2016. - 370 с.

5 Мустафин Т.Г. Обобщенные условия Йонсона и описание обобщенно-йонсоновских теорий булевых алгебр / Т.Г.Мустафин // Математические труды. - Новосибирск, 1998. - Т. 1. - № 1. - С. 135-197.

6 Ешкеев А.Р. Совершенные йонсоновские теории / А.Р.Ешкеев // Третья международная конференция по алгебре: тезисы докл. - Красноярск, 1993.

7 Yeshkeyev A.R. On Jonsson sets and some their properties / European summer meeting of the association for Symbolic Logic: Logic Colloquium '14 / A.R.Yeshkeyev // The Bulletin of Symbolic Logic. - 2015. - Vol. 21. - No. 1. - P. 34-103.

8 Yeshkeyev A.R. Properties of central type for fragments of Jonsson sets / European summer meeting of the association for Symbolic Logic: Logic Colloquium '15 / A.R.Yeshkeyev // The Bulletin of Symbolic Logic. - 2016. - Vol. 22. - No. 3. - P. 429, 430.

9 Yeshkeyev A.R. Cosemanticness and JSB-property for Abelian Groups / European Summer Meeting of the Association for Symbolic Logic: Logic Colloquium '16 / A.R.Yeshkeyev, O.I.Ulbrikht // The Bulletin of Symbolic Logic. - 2017. - Vol. 23. - No. 2. - P. 255, 256.

10 Poizat B. A Course in Model Theory / B.Poizat. - Springer-Verlag New York, lnc., 2000. - P. 445.

11 Биркгоф Г. Современная прикладная алгебра / Г.Биркгоф, Т.Барти. - М.: Мир, 1976. - С. 400.

12 Ешкеев A.P. JSp-косемантичность и JSB свойство абелевых групп // Siberian Electronic Mathematical Reports / A.Р. Ешкеев, О.И. Ульбрихт. [Электронный ресурс]. - Режим доступа: http://semr.math.nsc.ru. - Вып. 13(2016). - C. 861-874.

\title{
А.Р. Ешкеев, Г.А. Уркен
}

\section{Йонсондық теориялардың рұқсаттылылығы және ұқсастылығы}

\begin{abstract}
Мақала йонсондық теорияларды рұқсаттылылық, интерпретациялануы, синтаксистік және семантикалық ұқсастылық ұғымдарымен байланысты. Айтылған жаңа ұғым йонсондық теориялар үшін синтаксис және семантикалық ұқсастық ұғымын жалпылайды. Рұқсаттылылық, интерпретациялау, басымдылық және ұқсастық ұғымдары қарастырып отырған морфизмдерге қатысты йонсондық теориялардың семантикалық модельдің анықталған формулалық ішкі жиындарды сақтауының зерттеу барысында өте маңызды рөлін атқарады. Негізгі мысал ретінде буль алгебралар теориясы қарастырылды. Бұл ұғымдар бір теорияның басқа теориямен рұқсаттылылығы ұғымымен байланысты. Бұл жұмыстың қызығушылығы осында қарастырылған мысалдар рұқсаттылылық, интерпретациялау және ұқсастылықты әртүрлі сигнатурадағы алгебраларда зерттелуі мүмкін екенін көрсетті. Мақалада ұғымдардың негізгі анықтамалары және әріректегі зерттеулердің негізгі бағыттары берілген.

Kiлm сөздер: йонсондық теория, семантикалық модель, йонсондық теориялардың рұқсаттылылығы, интерпретациялануы, басымдылығы, синтаксистік және семантикалық ұқсастылық.
\end{abstract}




\title{
А.Р. Ешкеев, Г.А. Уркен \\ Допустимость и подобие йонсоновских теорий
}

\begin{abstract}
Статья связана с понятиями допустимости, интерпретации, синтаксического и семантического подобия для йонсоновских теорий. В рамках изучения сохранения определимых формульных подмножеств семантической модели йонсоновской теории относительно рассматриваемых морфизмов понятия допустимости, интерпретируемости, доминируемости и подобия играют очень важную роль. В качестве примера рассмотрена теория булевых алгебр. Эти понятия связаны с допустимостью одной теории с другой. Одним из интересных моментов этой работы является то, что представленные примеры допустимости, интерпретации, подобия изучены в различных сигнатурах. В статье даны ключевые определения понятий и основные направления дальнейших исследований.
\end{abstract}

Ключевые слова: йонсоновская теория, семантическая модель, допустимость, интерпретируемость, доминируемость йонсоновских теорий, синтаксическое и семантическое подобие.

\section{References}

1 Mustafin, T.G., \& Nurmagambetov, T.A. (1987). Vvedenie v prikladnuiu teoriiu modelei [Introduction to applied Model Theory]. Karaganda: Izdatelstvo KarHU [in Russian].

2 Mustafin, T.G. (1990). On similarities of complete theories. Logic Colloquium '90. Proceedings of the Annual European Summer Meeting of the Association for Symbolic Logic. Helsinki.

3 Mustafin, Y. (2002). Quelques proprietes des theories de Jonsson. The Journal of Symbolic Logic, Vol. 67.2, $528-536$.

4 Yeshkeyev, A.R., \& Kasymetova, M.T. (2016). Ionsonovskie teorii i ikh klassy modelei [Jonsson theories and their classes of models]. Karaganda: Izdatelstvo KarHU [in Russian].

5 Mustafin, T.G. (1998). Obobshchennye usloviia Yonsona i opisanie obobshchenno-ionsonovskikh teori bulevykh alhebr [Generalized Jonsson's conditions and a description of generalized Jonsson theories of Boolean algebras]. Matematicheskie trudy - Mathematical Works, Vol.1, 1, 135-197. Novosibirsk [in Russian].

6 Yeshkeyev, A.R. (1993). Sovershennye ionsonovskie teorii [Perfect Jonsson theories]. Tretia mezhdunarodnaia konferentsiia po alhebre. Tezisy dokladov - The Third International Conference on Algebra. Theses of reports. Krasnoyarsk [in Russian].

7 Yeshkeyev, A.R. (2015). On Jonsson sets and some their properties / 2014 European summer meeting of the association for Symbolic Logic: Logic Colloquium '14. The Bulletin of Symbolic Logic, Vol. 21, 1, $34-103$.

8 Yeshkeyev, A.R. (2016). Properties of central type for fragments of Jonsson sets 2015 European summer meeting of the association for Symbolic Logic: Logic Colloquium '15. The Bulletin of Symbolic Logic, Vol.22, 3, 429, 430.

9 Yeshkeyev, A.R., \& Ulbrikht, O.I. (2017). Cosemanticness and JSB-property for Abelian Groups / European Summer Meeting of the Association for Symbolic Logic: Logic Colloquium '16. The Bulletin of Symbolic Logic, Vol. 23, 2, 255, 256.

10 Poizat, B. (2000). Course in Model Theory. Springer-Verlag New York, lnc.

11 Birkgof, G., \& Barti, T. (1976). Sovremennaia prikladnaia alhebra [Modern Applied Algebra]. Moscow: Mir [in Russian].

12 Yeshkeyev, A.R., \& Ulbricht, O.I. (2016). JSp-kosemantichnost; i JSB svoistvo abelevykh hrupp [JSp-kosemanticness and JSB property of Abelian groups]. Siberian Electronic Mathematical Reports, Vol. 13, 861-874. Retrieved from http://semr.math.nsc.ru [in Russian]. 